\title{
Traditional body care of women in Madura Island
}

\author{
Perawatan tubuh perempuan Madura \\ Ririn Arisa Putri ${ }^{1}$, Sharyn Graham-Davies ${ }^{2}$, \& Myrtati D. Artaria $^{3}$ \\ ${ }^{1}$ Study Program of Anthropology, Faculty of Cultural Studies, Universitas Brawijaya, Malang, Indonesia \\ ${ }^{2}$ Auckland University of Technology, Auckland, New Zealand \\ ${ }^{3}$ Department of Anthropology, Faculty Social and Political Sciences, Universitas Airlangga, \\ Surabaya, Indonesia \\ E-mail: myrtati.artaria@fisip.unair.ac.id
}

\begin{abstract}
Most of Indonesian family systems adhere to the patriarchy system, in which the husband has the authority to make decision. It is also the case in Prenduan Village in Sumenep region in Madura Island. This research aimed to know how the body care in Prenduan women in Madura, and how the women's view upon their body cares. It is interesting to see the point of view of women in Madura, whether they do it for themselves, or for the husbands. This is a qualitative research. We used indepth interviews and observation to gather the data. We find that body care of Prenduan women in Sumenep, Madura Island has the purpose to make the husband happy and satisfied. For teenage girls, the purpose is for their health, and to prepare them so that they can function well in their family when they get married. They consider using traditional potion is better than those of modern medication made of chemical materials. The focus of the body care practice is the position of a woman as a partner, who is in the position to make the husband happy and satisfied, and also to take care of the family well, in which among the Madura women it is considered as an honor to have such role.
\end{abstract}

Keywords: body care; health; beauty; traditional potion; jamu

\begin{abstract}
Abstrak
Sebagian besar sistem keluarga Indonesia mematuhi sistem patriarki, di mana suami memiliki wewenang untuk membuat keputusan. Demikian pula di Desa Prenduan di daerah Sumenep di Pulau Madura. Penelitian ini bertujuan untuk mengetahui bagaimana perawatan tubuh pada wanita Prenduan di Madura, dan bagaimana pandangan wanita terhadap tubuh mereka. Sangat menarik untuk melihat sudut pandang perempuan di Madura, apakah mereka melakukannya untuk diri sendiri, atau untuk para suami. Ini adalah penelitian kualitatif. Kami menggunakan wawancara mendalam dan observasi untuk mengumpulkan data. Kami menemukan bahwa perawatan tubuh wanita Prenduan di Sumenep, Pulau Madura memiliki tujuan untuk membuat suami bahagia dan puas. Untuk gadis remaja, tujuannya adalah untuk kesehatan mereka, dan untuk mempersiapkan mereka agar mereka dapat berfungsi dengan baik di keluarga mereka ketika mereka menikah. Mereka menganggap menggunakan ramuan tradisional lebih baik daripada obat modern yang terbuat dari bahan kimia. Fokus dari praktik perawatan tubuh adalah posisi seorang wanita sebagai mitra, yang berada dalam posisi untuk membuat suami bahagia dan puas, dan juga untuk mengurus keluarga dengan baik, di mana di kalangan wanita Madura dianggap sebagai suatu kehormatan untuk memiliki peran tersebut.
\end{abstract}

Kata kunci: perawatan tubuh; kesehatan; kecantikan; ramuan tradisional; jamu

\section{Introduction}

Most of Indonesian family systems adhere to the patriarchy system, in which the husband has the authority to make decision, including the Madurese in Prenduan village in Sumenep region. Patriarchy is when the men-husbands--have the most important position in the family as the decision maker; meanwhile the women -wives-- play the roles in the domestic realm such taking care of the family, and serving the husbands (Friedl 1987:165). A wife should obey her husband as the leader of the family. The wife has the domestic roles, and maintaining the family in harmony. Taking care of the body is considered to be one of the ways to maintain harmony in the family.

For Madurese women, looking attractive for the husband is one of the ways to make the husband happy and satisfied. Every woman has her own way to be able to look attractive. Caring herself 
means a woman takes care of her health, body shape, and beauty. There are many Madura women when taking care of their health, body shape, and their beauty, they use traditional potions they call jemo or jaтu. These traditional potions are made of herbs. They also use other local knowledge for maintaining their health and beauty.

The people of Madura believe the efficacy from the traditional potions; that are already existed from generations to generations by using the natural ingredients. Consuming jamu has already become a habit of the society especially the women. Madurese traditional potions have stronger smells that come from the spices. The taste is mostly bitter. Sometimes they add vinegar, so that there is the bitter and sour taste. Meanwhile, the taste of Javanese traditional potions, for example, are sweeter.

The traditional potions are consumed by the Madurese women because they want their bodies remain healthy. They believe that because of the traditional potions, their immune system is stronger against various diseases. This is useful so that they can maintain the wellbeng of the family. According to Huub de Jonge (1995), Madurese women are wellknown to be shapely and slim. They also are well known in their good ability to satisfy their husbands.

In Madura, more women consume tradition potions compared to the men. They think that they should be responsible in the domestic domain, and also responsible for taking care of themselves. Most women have the habit of consuming traditional potions starting well before they get married.

These are the reasons why the researchers want to know how the Madurese women take care of their bodies, how they use local knowledge for bodily care, and how they use traditional potions to maintain their health and beauty.

\section{Methods}

It is a qualitative research. The study utilized indepth interviews and observations to gather data. The data were from the interview scripts, field notes, personal documents, notes, memos, and other formal documents. The location of this research was in Prenduan Village, Pragaan District, Sumenep Region, in Madura Island. We interviewed 8 women from the village of Prenduan. We documented the data using notes, recorder and camera. We used ethnographic approach for analyzing the data, and wrote the report.

Figure 1 is the map of the location of our research. It is a remote area in Madura, where goods are transported from a bigger city only once a week. The traditional market opens once a week, so that housewives wait for the market to be opened to buy food for them to cook for her family. Life is not always easy, but the adaptation for taking care of their health has developed from one generation to another.

\section{Results and Discussion}

\section{The education of the people in Prenduan Village}

Education is a process to change someone's or a group of people's attitude and the behavior to make the human mature. This changes can be done through education and training. Education is not only a result of a formal education, but also through informal education and experience of the individuals. Schools are the means of education in which the society get their formal education. Meanwhile, the informal education is various experiences, and also from the experience of other people around them, and from their cultural social lives.

In Indonesia, including Madura, there are schools that are based on religion. The Islamic based schools have teaching and learning activities held on Saturdays until Thursdays, but on Fridays they have school holiday. On the contrary, the public schools have holiday on Sundays and schools have activities from Mondays until Saturdays. Prenduan village is famous for its "Al Amin" Islamic boarding school, in which that boarding school is the biggest boarding school in Madura that takes the Islam religion as the priority and the teaching is balanced with the general subjects. 


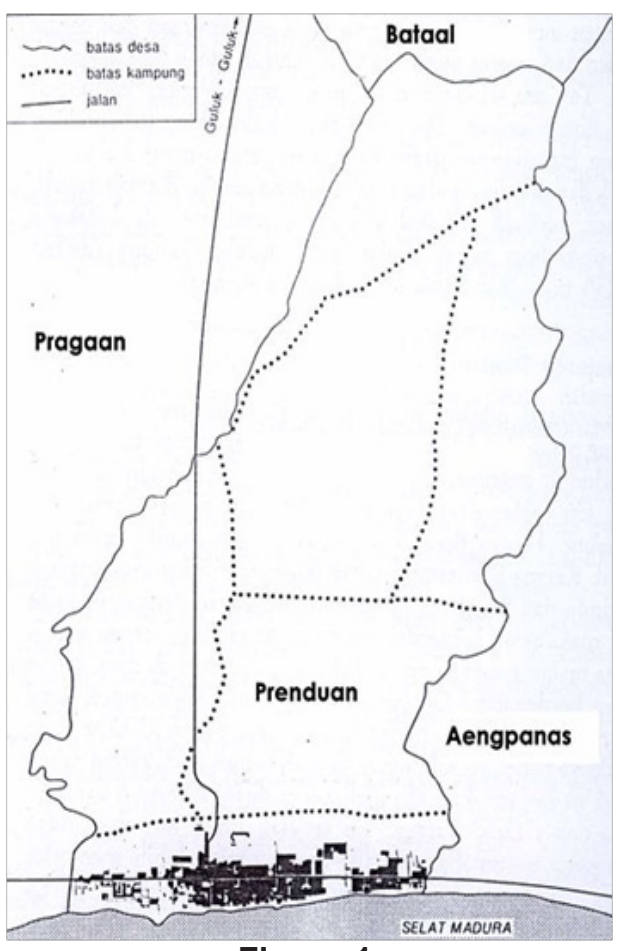

Figure 1.

The location of Prenduan Village

\section{The caring for health}

The people in Prenduan village are mostly very active, so that they need energy for their daily activities. They consume fish and vegetables to support their source of energy. The location of this village is near the beach, and they also do farming. Therefore the societies have no difficulties to get fish and vegetables to consume. The villagers' houses are equiped with personal toiletries. The societies also do not have difficulties to obtain clean water because there is clean water from PAM--Government Water Company--and some of them have already used the pumped well.

Prenduan village has adequate health facilities to get the medical help. However, their habits to choose the traditional medication to handle their health problems are not easy to change. For examples, for giving birth female villagers choose to go to a shaman instead of going to a midwife. It is in line with Mrs. Hs' statement (26 years old). She said "if we go to the dukun bayi--traditional health carer or shaman who help women to give birth, we also ask the dukun to check up the pregnancy too. (In our opinion), sometimes the midwives have wrong predictions regarding our pregnancy. Besides that, the midwives also go to the dukun too, so that we trust the dukun. "In some other places, traditional healers and traditional potions are also the preferable options because of various reasons, such as in Ghana (Tabi et al. 2006).

The majority of the villagers choose to use some home-made traditional potion, or they can buy the potion; it is because they believe that the traditional potions are better than modern medication. However, they said that they do not resist the progress of the technology in the medical world. There are people who come to the health experts or paramedic to consult about diseases that they have, when they can afford it. The people in Prenduan village use two kinds of treatment, the traditional way, and the modern way. When using the traditional treatment they use ingredients from boiled plants that have benefits to keep the body healthy and to cure or heal the diseases.

\section{Cultural and social conditions}

Madurese people are patriarchaat society, including the marriage system. The man-husband-has the power in taking the decisions related to the household business. However, the settlement of 
the newly wed after the marriage ceremony is matrilocal. It means that the married couple must live in the tanean lanjang, together with the woman's parents. A woman who is already married will stay in her house or in the parents' house, meanwhile a married man will move to the woman's house or the woman's parents' house. Sometimes he must live with his parents - in - laws (Latief 2002). In one family area there are some houses of family members. The form of the housing is called Tanean Lanjang patterns. Tanean Lanjang pattern is to the oldest pattern in Madura family settlement (Jonge 1989).

\section{The body cares of the Madurese Women}

Generally, the way the Madurese women wear their clothes have typical characteristics. They wear clothes that cover up to hands and ankles; such as long dresses, long skirts, and veils for covering the hair and neck. Those covered parts are considered aurat--forbidden to be seen-- based on the provisions in Islam. Most of them wear local batik motive, unique to Madura Island, for long dresses, long skirts, or sarong.

Madurese women wear the sarongs in their activities at home or outside of the house if they only chat with their neighbors. Wearing the sarongs has already become a habit until now. Although they wear towels after they take a bath, Madurese women still look for the sarongs that they wear after they take a bath. They use towel to dry their bodies after taking a bath and then the dried bodies are covered with the sarongs. After they are married, the use of sarong after taking a bath is also used to cover all body parts in the process of evaporation with incense. This activity is devoted for making the husband satisfied, because it will make their bodies smell good.

The Madurese women have different characteristic from Javanese women. According to Rifai, "although Madura Island is East Java, the island is separated from Java Island, and the characteristics and physical appearance of Madurese women are different from the Javanese" (Rifai 2007). "We do not see softness at the faces of most Madurese women, because the bone structure is robust, so that they appear that way" (Ardhie 2014). The Madurese women have big breasts and plump bodies (Jonge 1995). They say that the big breasts of the Madurese women are because they never wear kemben like Javanese women. Kemben is a piece of cloth worn on the breasts areas surrounding the body to make the breasts flat. Acording to Jonge (Rifai 2007) it is related to the Madurese woman activities that they often do "nyo'on", an activity to bring bottles, food basket, yields and sacks on top of their heads. Wearing the "kemben" may restrict their activities.

The image of the Madurese women is not only about the slim body with plump shapes, but Madurese women traditionally also have more strengths compared to Javanese women (Jonge 1991:16). It is related to the habits of the Madurese women in consuming the traditional potion; they have started to consume the traditional potion since they were in puberty period; and they are used to physical work since they are young. Consuming the traditional potion is considered to be the tradition. Their awareness to consume the herbs is based on their knowledge they get from their parents. Although there is a risk, such as it is impossible to foresee the results and possible complications of its use (van Bogaert 2007), drinking the herbs becomes an important thing because Madurese women feel the good benefit of the herbs for their bodies, therefore; the habit to consume the herbs is passed on to their children.

\section{The woman activities as a housewife}

The way the Madurese people respect their women is that they consider women as the symbol of honor for the husband or the family. After the marriage, the husband lives at the house of the wife, but when deciding something for the family, it is the husband who is in charge. This especially is influenced by the Islam religion that they follow obediently. Islam religion becomes the majority of religion embraced by the people in Madura Island.

Every morning, after finishing the subuh prayer, a wife does not go back to sleep again but she cleans the house such as sweeping the whole house including the yard in front of the house. After finishing the household chores, a wife goes to the market located not too far away from her house to buy 
materials for cooking the food. After she arrives from the market, she cooks the food for her husband and children. If the wife works at an office or somewhere, after finishing the duties as a wife at home, she goes to work. Some of the men take the wife to go to work, but some of the women go to work by public transport. The working hours depend on the type of job. Many of the women work as sellers at the market. The activities are from morning to afternoon. Women in Madura usually work for helping the economy of the family. Both the wife and the husband decide together whether the wife should go to work. Most of the time the wife works because of the low family's income. Therefore, the husband gives permission to his wife to work.

When a woman does not go to work, her main job is taking care of the kids and the house. These chores are not always easy. Taking care of the children while keeping the house to be clean, tidying the clothes, and being responsible for cooking to provide the meals everyday are the other responsibilities of a wife. Those women clean the house in the evening, sweeping the entire parts of house and the yard. Then, she can clean herself by taking a bath. After that, she sometimes has to go out of the house to socialize with her neighbors.

\section{Women in the economic sector}

In the economic sector, people in Madura earn their money from farming, fishing, trading, and becoming the government workers--civil servants (Kuntowijoyo 2002). Women have important role in the family's economy. They sell goods at the market. Most sellers in the market are women. Grocery sellers in the shopping center are mostly women too. The people in Madura are mostly farmers and fishers because the island is surrounded by the sea (Rifai 2007). In the farming sector, Madurese men and women have division of work equally, in this case the men hoe and plow the rice field, while the women weed and seed the rice field. Madurese women who live in the coastal areas generally work as fish sellers, and dry the fish that the husband captured from the sea.

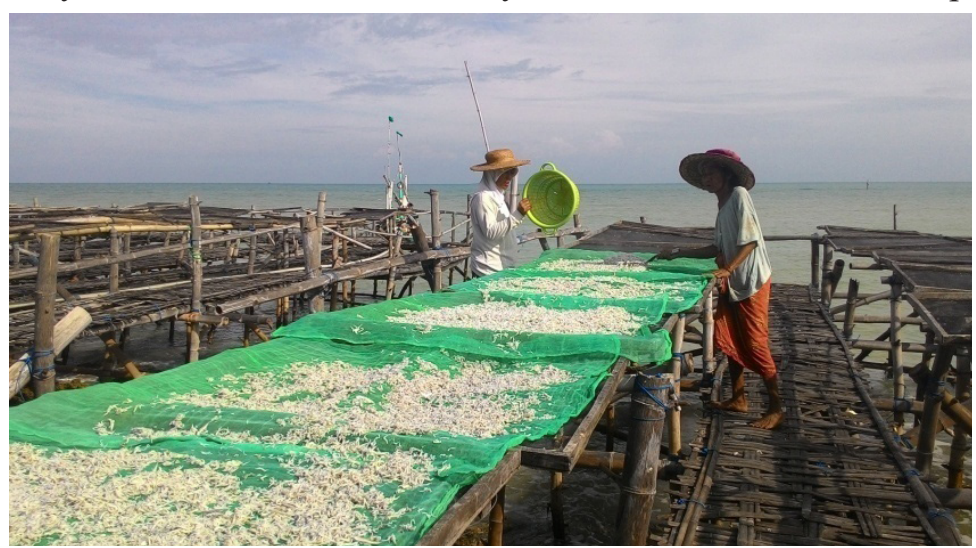

Figure 2.

The process of drying the fish

(Source: Personal documentation)

When the husband acquired some money, he gave the money to the wife. The wife in Madura manages the financial matters of the family. The position of the wives is relatively the same as the position of husbands' in handling the economy responsibility and the continuity of their household (Kusnadi et al. 2006).

\section{The ways Madurese women take care of their bodies}

\section{The use of the traditional potions}

In Indonesia, there are traditional potions that are useful for maintaining health and curing some diseases, including those people in Madura. Most women in Madura prefer traditional potions for maintaining their health and beauty. This is a strong tradition that is passed from one generation to another. It is well known that women fron Madura Island are good in satisfying the husband. The 
traditional positons are called jamu, and they are made of herbs and spices. Most of the taste of Madurese jamu is bitter. There are various jamu, that each has its own function in maintaining health and beauty. The good reputation of Madura jamu has been well known so that other women in other areas of Indonesia sometimes consume them too. The most well known reputation is for maintaining the capability of the wife in sexual relationship, so that it helps maintaining the relationship between husband and wife (Jonge 1991).

The young women have the pressure to consume the traditional potions from the parents, based on the local knowledge upon the importance of consuming the traditional potions. In men, consuming the traditional potions is for maintaining their health and to cure some diseases. Maintaining good sexual relationship using traditional potions is only for the women. There is a belief among these people that when a woman consume traditional potions regularly, she will get a husband more easily than those who do not consume them regularly. This is because the woman would be healthy, more beautiful, and has good smell; those that are appealing for most men.

According to our informant, most men in Madura consume less traditional potions compared to the women. For example, Mrs SI (55 years old) who has one boy and two girls stated that:

"I do not give traditional herbs to my son, although there was jamu for the health of a young man. However, for my daughters, I give them traditional herbs from the time they get their first menstruation, to make their menstruation more regular, and also make them smell good."

According to Mrs. SI, example of a traditional potion for men is "jamu sehat lelaki" (herbs for men's health). It is made of some ingredients such as green bettel leaves, ginger, lempuyang, and temulawak. Those ingredients are mixed before they drink if. The benefit of this jamu is to make a better blood circulation so that the body stays healthy. Another example of a traditional potion is the one that is rubbed onto the body. One kind of traditional potion that is rubbed onto women's reproduction organ is very well known also outside of Madura. The people in Madura call these lolor.

One example of Madura jamu is made of mengkudu fruit and betel leaves. Mengkudu is believed to be able to cure hypertension, and lower the cholesterol. They believe that they can maintain blood pressure using this fruit. Mrs. $\mathrm{Dj}$, a 60 year old, said that she had headache all the time. After consuming the fruit everyday, she feels better.

One well know jamu for the women is galian rapet. This is a traditional potion that is believed to make the women's reproductive organ smells good and in good condition to satisfy the husband. There is a belief that woman's vagina should be tight and not too slippery in order to satisfy the husband, and that is the job of galian rapet to make sure that the woman has that condition.

Another well known traditional way in Madura to maintain this condition is using tongkat Madura-Madurese stick, that is used before the woman has intercourse. The purpose is the same, but the difference is that the galian rapet is drank regularly, while the stick is used on the woman's reproductive organ when it is needed.

One of the informant, Mrs. Zn-a 41 years old, said that she chose to consume the galian rapet instead of using the Madurese stick because she was afraid that something bad happened to her reproductive organ. Therefore, Mrs. Zn did not use the Madurese stick. However she admitted that she never heard of any problems from other women who used the Madurese stick.

\section{Traditional potions for Madurese teenage girls}

Drinking jamu is also the habit of Madurese girls. Since they are 5 years old, they have already been introduced to jamu, such as jamu beras kencur to increase the appetite and jamu sinom for taking care of stomachace.

Puberty is the beginning of a woman maturity. There is a tradition of early marriage in Madura. Therefore once a girl has her menarche, whe begins to prepare for her marriage. One of them is 
consuming traditional potions for her reproductive organs more regularly. The purpose is also to make her periode more regular. Regular menstruation is one of the signs of healthy reproductive system. During her menstruation, a woman should not consume other jamu for other purposes. The jamu for the girls are galian putri, jemo pakak, and jemo bengkes. According to one of our informants:

\begin{abstract}
"Girls must be clean and healthy. Girls consume jamu for these purposes. It is fine because when I was a girl, my mother also gave the jamu when I got my menstruation. We also avoid abnormal vaginal discharge by consuming betel leaves. Madurese women get used to drinking jamu, so that when we do not drink the jamu, it seems there is something missing. Nowadays, it is much easier because we can buy jamu at the stalls. We also make homemade jamu from temulawak, kunci, betel leaves, coriander, and perawas that are pounded together until they are soft, and then we put some water. The function is to make the blood menstruation clean" (SI, 55 years old).
\end{abstract}

The young women consume the jamu also for keeping their bodies slim. The use of the plants such as manjakani, betel leaves, and kunci, are the ingredients for avoiding abnormal vaginal discharge and irregular menstruation. The betel leaves contain the atsiri oil that contains betlephenol, chvicol, and eugenol that can kill the germs; an antioxidant, anti fungal and anti inflammation (Carolia \& Noventi 2012). They can also eliminate body odor, bad breath, vaginal odor, and vaginal discharge that is caused by germs and fungus. Meanwhile, the turmeric plant has the benefit for curing various diseases, such as killing germs that cause the abnormal vaginal discharge.

\title{
Traditional potions for couples
}

For most people, marriage is a very happy moment, not only for the couple who are getting married but also for both families of those couple. The preparation before the marriage is months before the ceremony. Taking care of the body before the marriage is very important for the woman. For the bride to be, body is prepared very well so that she looks very attractive during the ceremony. The woman's body who is going to be the bride must be taken care by using "cold face powder" and scrub-lolor, made of traditional herbs.

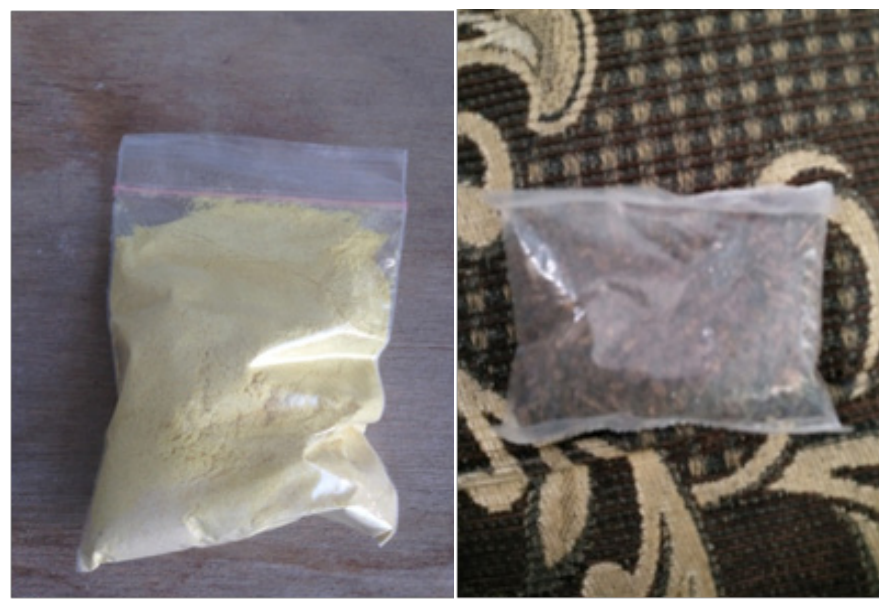

Figure 3.

Scrub and wood incense

(Source: Personal Documentation)

The way they apply lolor is by scrubbing the traditional ingredients on the whole body, and let it be dried for some minutes. After that, she rinses the ingredients and takes a bath. The benefit of applying the scrubs is to make the skin smooth and soft and to clean the skin, because the scrub can lift the dead cells. It is believed that it also increases the blood circulation so that the body feels fresh.

The use of ratus incence is recommended for a bride. After applying the scrubs on the whole body and clean it, then, the incense from fragrance wood is burnt and evaporated to the whole body while 
wearing a cloth, or a sarong, wrapped around her body. The cloth or sarong is worn to cover the body, while the incense is burnt inside the sarong, to make her smelling good from head to toe. The Ratus incense on the vaginal area is believed that it can reduce the mucus and eliminate bad odor.

The Madurese traditional potions are not only applied on the surface areas of the body, but there are those that are consumed by the bride to be before the marriage. The traditional potions have benefits to eliminate the body odor and reduce the sweat. The herbs are boiled in water, and she drinks it everyday for 7 days before the marriage ceremony.

A day after the marriage up to 7 days after, the bride keeps using the lolor and the ratus incense. They may also consume a jamu for another purpose. One of our informants stated:

"After I got married, I drank jamu that is intended for me to have a baby sooner. I drank it twice a week at 9 or 10 in the evening and there was not any provision related to the days. The jamu was put out side of the house to make it cold, before i drank it. I made the jamu myself" (Mrs. Zn, 41 years old) .

After the marriage, most couples want to have a child as soon as possible. This is not only expected by the couple, but also by the extended family from both sides. The wife drinks the jamu to help her uterus to be more fertile. This jamu is made of a local plant called dadapan serep. This plant they can grow around the house easily. After giving birth, women in Madura consume jamu called galian rapet. This jamu is believed to make the reproductive organ to be healthy and tight again like a virgin.

\section{Traditional potions during the pregnancy and giving birth}

In the modern era nowadays, technology improves significantly. Although the technology improvement in the medical areas are rapid, the somen in Madura do not want to let go the traditional ways in keeping their bodies healthy, fit, and beautiful. During their pregnancy, many women in Madura still prefer going to dukun bayi, a traditional practitioner who help the women in delivering their babies.

The reason Pregnant women choose going to the dukun instead of going to a midwife or going to the public health center during the pregnancy is because they feel more comfortable with the dukun. Most women think that dukun is more reliable and easy to access. Usually a dukun learned her skills from her mother, or a senior female relative. Most women are reluctant to go to a medical doctor because it is considered more difficult to access, more expensive, and sometime they are scared of the equipments that they have. More importantly, many of the geneacologist are males. Most husband do not allow their wife to be touched by male geneacologist.

Most women in Madura prefer dukun because they consider the motherly approach of the dukun is good for their psychology. The soft touch and the activities she does are not too daunting, and she gives comfortable feeling to the pregnant mothers. The dukun answers any questions they have, they give motherly suggestions, and tells them what to do and not to do.

$\mathrm{n}$ the belief of Madura ethnic group, during the early pregnancy period, the pregnant women are forbidden to drink jamu because it can give bad impacts to the baby in the womb. When the pregnancy is seven months old, the dukun gives jamu that must be consumed regularly until the mother gives birth. This jamu is for maintaining the condition of the mother, so that she will be strong when she is delivering the baby.

The jamu for the mother is made of coconut oil and egg yolk. The coconut oil can be substituted by honey, but the coconut oil and the honey cannot be mixed at the same time. The ingredients are mixed in one glass without being stirred and then the woman drink it directly. This should be consumed every once in ten days, until she gives birth. One of our informants said that:

"When a woman is going to deliver a baby or the pregnancy is seven months, coconut oil is made from boiled red coconut water (nyur ecu) and then the oil is mixed with egg yolk; that jamu is drunk directly without being stirred by the pregnant woman; the function is to make 
the mother strong when she delivers the baby, and the baby will be healthy too. It is consumed once in every ten (10) days before the birth time since the pregnancy is seven months old." (Mrs. Dj, 60 years old).

After a woman delivers a baby, her outer reproductive organ will be plastered with the Madurese traditional potion so that the vagina will be healthy and tight again after giving birth, without being stitched.

"The cloth is folded and given the mixture of ashes made from a burnt tree and filtered so that it is only soft ashes, and we added tamarind, vinegar, and salt; and then the cloth is put on the vagina, worn like a sanitary napkin. After that, we give param, made of betel leaf with pepper mixed with vinegar, and drank it after the woman delivers the baby. She can walk directly afterwards." (Mrs. Dj, 60 years old).

They also consume jamu that is drunk regularly after giving birth. That jamu is believed to make the body recover sooner, and make the blood circulate better after the woman delivered a baby. Mrs. Hs (26 years old) stated that:

"I used the jamu to make my body recover after delivering my baby. In my hometown women believe that we must drink the jати. If we did not drink the jamu, the leucocyte will not be enough for us to recover, and that may cause death."

They also believe that consuming jamu after giving birth will help the mother to produce more breast milk. The jamu for more breast milk is made of kodu--Mengkudu fruit, that is mixed with temulawak and onions. The ingredients are pounded into powder, and they add warm water. This is believed to clean the remaining blood on the womb after delivering the baby.

Another function for consuming jamu after giving birth is for avoiding the body from becoming much bigger, so that the woman stays slim. They believe that the jamu also eliminates body odor, and make the face and skin bright and shiny.

Around 40 days after giving birth, the dukun observes the woman again, and gives another form of јати. The purpose is to maintain her health, and to produce more breast milk. Within those 40 days, the dukun visits the woman at 6 am and $4 \mathrm{pm}$, to help bathing the baby.

"Before a mother delivers the baby, the husband collects a coconut shell and a cengkel--corn stem. After they are dry, the husband burn them into charcoal. He puts it in a bucket, and mixes with water and salt. After it is filtered, it is mixed with vinegar." (Mrs. Hs, 26 years old).

"Use the lime water, and burnt coconut shell. Mix them with warm water; so that it becomes thick powder, and wait until it is cold." (Mrs. Dj, 60 years old).

The benefit of parem is to return the body into the slim figure that they had before giving birth, to tighten the muscle of the belly after delivering the baby, and to make the blood to circulate better. There are two kinds of parem, for the upper and lower part of the body. This parem is used until 40 days after giving birth.

During the 40 days after giving birth, the mother should wash her hair everyday. It is believed that it can cause the woman to produce more breast milk. She also use the incense regularly to make her body and hair more fragrant.

To minimize the fat for accumulating on the belly after giving birth, the women use bengkung and gurita. This is a long cloth that is wrapped around her body especially the belly area. Bengkung is a cloth of $15 \mathrm{~cm}$ width, and $12 \mathrm{~m}$ in length. She also put traditional potions on her belly to help the muscle to return to its original shape after stretched during pregnancy. Gurita serves the same purpose, but the cloth is wider and shorter compared to bengkung. Gurita has many small ropes attached, so that the shape is like a gurita —octopus. 


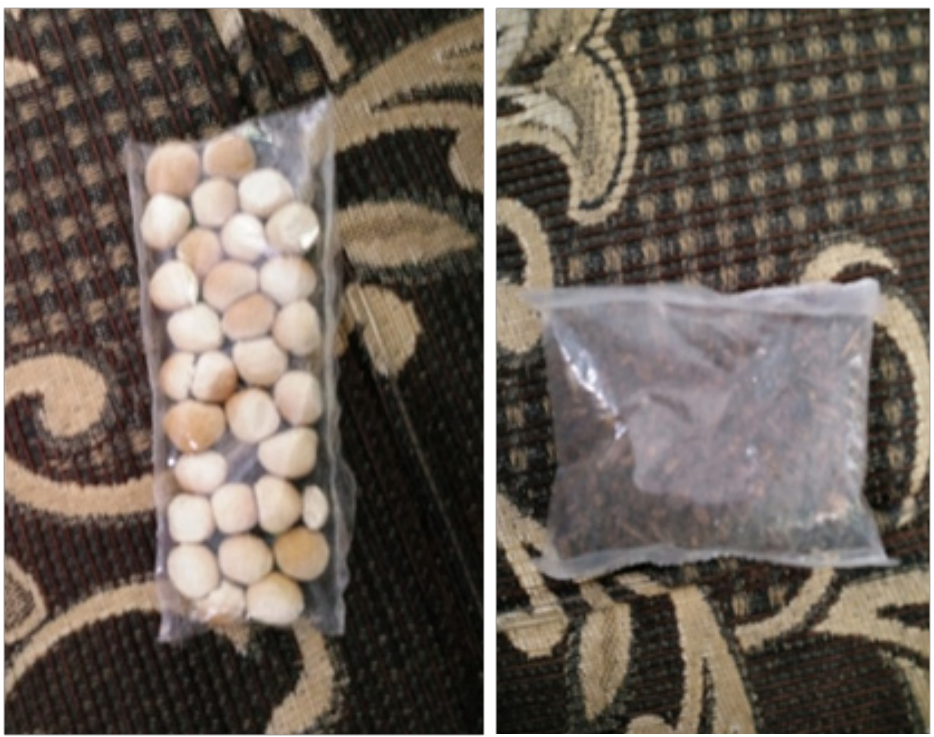

Figure 4.

Parem (bottom scrub powder) and Incense (Source: Personal Documentation)

During those 40 days after giving birth, when she sits and sleeps, they believe that the position of the woman's feet must be straight and tight, so that she does not get varicose vein and the reproduction organ becomes tight a gain. Women who do not want to get pregnant again, also consume a certain kind of jamu to prevent them from being pregnant. This type of jamu is believed to have "hot character", so that the reproductive organ-uterus-- is not in a condition to accept a fertilized egg.

\section{Jamu for healing and caring for health}

In other places, such as Jawa and China, traditional potions are used for men and women. In China for example, traditional potions for hair anti-aging (Hui et al. 2002), and jamu kuat for Javanese men. Basically, Madurese women want to be beautiful, so that they do various efforts to take care of their health and to make them more attractive. Nowadays there are modern cosmetical and chemical products for maintaining beauty, but jamu is still the most prefered, because it is made of natural ingredients, and is considered safer.

For women 40 years and above, consuming the jamu is also for keeping their health. Most of them consume the mengkudu boiled in water so that they do not get sick easily. Their purpose to keep their body from bad odor is also served by consuming the jamu regularly.

\section{Conclusion}

Based on our interview with our informants, jamu consumption in Madura is mostly for women. The purposes are for keeping her good health, and most importantly for taking care of her body so that she is attractive to the husband. The point of view is that the responsibility for an ideal marriage is mostly at the hands of the wife. It is also the responsibility of the wife to keep herself attractive and fertile, in young couples. The point of view is that in marriage, the man should be served, and the woman serve the husband. It is a responsibility of the wife to satisfy the husband, by using traditional potions or jати or jemo. The tradition in consuming and using traditional potions are still practiced well in Prenduan Village. We assumed that it is also the case in other areas in Madura. Therefore the existence of the believe that women in Madura are good lovers for their husbands. The focus of the body care practice is the position of a woman as a partner, who is in the position to make the husband happy and satisfied, and also to take care of the family well, in which among the Madura women it is considered as an honor to have such role. However, when it comes to their household economy, the responsibility is balanced, both on the hands of the husband and the wife. 


\section{References}

Carolia N \& Noventi W (2016) Potensi ekstrak daun sirih hijau (Piper betle L.) sebagai alternatif terapi Acne vulgaris. Jurnal Majority 5(1):140-145.

Hui Z, Xinyu, Z and Hongmei C (2002) An experimental study of Hewei Jiegu potion in the effect of digestive system. The Journal of Traditional Chinese Orthopedics and Traumatology 9:004.

Jonge H (1995) Across Madura Strait, The Dynamics of an Insular Society: Stereotypes of Madurese. KITLV Press Leiden.

Jonge H (1989) Madura: Dalam Empat Zaman: Perdagang, Perkembangan Ekonomi, dan Islam. Jakarta: PT Gramedia.

Kuntowijoyo (2002) Perubahan Sosial dalam Masyarakat Madura 1850-1940. Yogyakarta: Matabangsa.

Kusnadi, Sulistiyowati H, Sumarjono, \& Prasodjo A (2006) Perempuan Pesisir. Yogyakarta: LKiS.

Tabi MM, Powell M and Hodnicki D (2006) Use of traditional healers and modern medicine in Ghana. International nursing review 53(1):52-58.

Van Bogaert DK (2007) Ethical considerations in African traditional medicine: a response to Nyika. Developing world bioethics, 7(1), pp.35-40.

Wiyata L (2002) Carok: Konflik Kekerasan dan Harga Diri Orang Madura. Yogyakarta: LKiS. 